\title{
The Implementation of Leverage Secondary Association through Stakeholder Approach in Reinforcing Brand Knowledge: The Case Study of Wanderlust, Local Tourism Agent, Indonesia
}

\author{
Iin Mayasari", Fatchiah E. Kertamuda, Handrix Chris Haryanto, \\ Mochammad Rivee Arham
}

\begin{abstract}
There are three main objectives of this study namely 1) analyzing the application of secondary association leverage in strengthening the Wanderlust company brand products, 2) analyzing the implementation of stakeholder approaches in supporting brand strengthening and the sustainability of Wanderlust, and 3) determining the extent to which the application of secondary association leverage, whose main orientation is in strengthening the brand and the sustainability of the company, basically directly or indirectly reinforces the cultural products of one region. This study uses a qualitative approach as a method for data retrieval. Case study research raised in this regard relates to the existence of tour and travel companies under the name of Wanderlust in strengthening the company's brand awareness. The interview approach with the owner of Wanderlust is the most appropriate method in its efforts to explore the processes carried out by Wanderlust in strengthening branding using the Leverage Secondary Association approach. Based on the results of empirical research that has been done it can be concluded that the leverage secondary association in the Wanderlust company has shown strength in the company. This can be seen from the four elements that support it, namely people, places, things, and other brands. These four elements have been optimally carried out by Wanderlust to support the sustainability of his company in order to create equity in his company.
\end{abstract}

Keywords: Wanderlust, secondary leverage association, brand equity.

DOI : https://doi.org/10.30596/ijbe.v1i1.3443

JEL Classification : M00, M3, M21

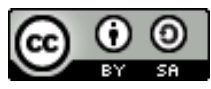

Published by IJBE, Indonesia | Copyright (C) 2019 by the Author(s) | This is an open access article distributed under the Creative Commons Attribution License http://creativecommons.org/licenses/by/4.0), which permitsunrestricted use, distribution, and reproduction in any medium, provided the original work is properly cited.

Cite this article as:

Mayasari, I., Kertamuda, F.E., Haryanto, H. C., \& Arham, M. R. (2019). The Implementation of Leverage Secondary Association through Stakeholder Approach in Reinforcing Brand Knowledge: The Case Study of Wanderlust, Local Tourism Agent, Indonesia. International Journal of Business Economics (IJBE), 1(1), 59-75.

Program Studi Manajemen, Universitas Paramadina

Jalan Gatot Subroto Kav. 97, Mampang, Jakarta 12790, Indonesia

*Corresponding Author: iin.mayasari@ paramadina.ac.id 


\section{IJBE}

International Journal of Business Economics, 1(1), 59-75, September 2019 http://jurnal.umsu.ac.id/index.php/ijbe

eISSN 2686-472X

\section{INTRODUCTION}

With the development of ease of transportation and access to information about tourism places, it has affected the community to tour the regions throughout Indonesia. Many tourism managers try to be able to meet people's needs well. This has led to the development of tourism management companies in Indonesia as tourism service providers.

In Indonesia, the number of tourism service companies has increased along with a significant increase in tourists. The Association of Indonesian Tours and Travel Agencies revealed that there are currently 7,000 travel companies registered in Indonesia in 2016. Competition between tourism service companies or Tour and Travel Agents is unavoidable. However, the competition must be healthy by prioritizing their respective advantages through creativity, innovation, and being able to keep up with developments in the digital era.

Wanderlust Adventure Indonesia (WAI) as one of the newly developing tourism service providers will certainly face a variety of challenges and competition with its competitors. Various challenges that are ready to be faced by as tourism service providers. WAI needs to do things that can strengthen its business through various ways. One way to do this is with brand awareness for the community of service users to be able to choose and determine what they want. Brand awareness is an important factor and is a major consideration in delivering their products or so that users or customers can remember or recognize the brand. Another challenge for tourism service providers is strengthening the positioning of the company, and this becomes very important so that it can run its business and can survive in the long term. To run its business, WAI seeks to strengthen all existing elements in order to support the understanding of brands from the community as a target market well.

As a newly developing company WAI will certainly strengthen through partnerships with similar companies and the government. Business in the field of tourism service providers is multifliyer effect. The involvement of various sectors, both private and government, such as hotels, land, sea and air transportation, tourism objects, and restaurants was also involved, so that the influence was significant in increasing economic growth. Therefore, collaboration, collaboration and building synergies to maintain consumer trust are important factors for all parties to the advancement of tourism in Indonesia.

The development of tourism in Indonesia began since the issuance of the Presidential Instruction No. 9 of 1969 concerning the Guidelines for the Development of National Tourism Development. There have been several efforts that have been made since then including maintaining/fostering the beauty and wealth of nature and culture of the Indonesian people as a tourist attraction; 2) providing / fostering transportation, accommodation, entertainment facilities and other tourism services needed, including cadre education; 3) carry out active and effective tourism promotion at home and abroad; 4) strive for smooth travel formalities and traffic of tourists and thus eliminate the elements that inhibit it; 6) directing policies and transportation activities, especially air transportation, as the main means to increase the number and smooth out the flow of tourists. Since then, from year to year there has been an increase in various things with various efforts to attract both local and foreign tourists to visit places and locations that are of interest to them.

Tourism in Indonesia is one sector that has great potential to support the wheels of the country's economy and increase state revenues. Various tourist locations with a variety of inherent 


\section{IJBE}

International Journal of Business Economics, 1(1), 59-75, September 2019 http://jurnal.umsu.ac.id/index.php/ijbe

eISSN 2686-472X

cultures can be found throughout the territory of Indonesia, increasingly attracting tourists both local and foreign tourists. This is strength for tourism managers in Indonesia. Tourism managers need to be able to improve the quality and service in order to attract tourists.

Indonesian tourism was ranked 9th in the world and number 3 in the Asian Region and reached the highest rank among Asean member countries. According to the Indonesian Tourism Competitiveness Index according to the World Economy Forum (WEF), there is an encouraging development in which Indonesia's ranking rose 8 points from 50 in 2016 to be ranked 42 in 2017. (https://travel.dream.co.id/news/ great-power-competitiveness-tourism-indonesia-skyrocketed-8rank-170407r.html The number of foreign tourist visits to Indonesia based on data from the Central Statistics Agency (BPS), as many as 4.2 million foreign tourists visited Indonesia during JanuaryApril 2017. Meaning, there was an increase of 19.34 percent compared to the same period in 2016 of 3.52 million people.

Wanderlust is initiated by a young couple who like to travel, Fransiskus Hanie and Venny Julliandhita see this hobby as a business opportunity that can provide benefits by utilizing their network and knowledge in the world of travel. Both of them agreed to start this travel business in January 2016 and set up a tour and travel company under the name Wanderlust Adventure Indonesia (WAI). Tour and travel that focus on local tourism in this country starts its business by opening a travel package to the location of domestic anti-mainstream tourism with stunning natural scenery, where it is very rare for tourists to know the location of the tour. To get his first customers, Hanie and Venny approached several relations and corporations who already knew them well to market WAI. Tour and travel located on Jl Komjen Pol. M. Jasin No. 57, Kelapa Dua, Depok is not only serving tourist trips, but also selling tickets online.

\section{Problem Formulation}

WAI as a local company has a problem related to brand awareness from the community and strengthening the company's positioning in order to survive in the long term. To run its business, Wanderlust seeks to strengthen all existing elements in order to support understanding of brands from the community as a target market well. These elements are summarized in the Secondary Leveraging Association concept which consists of other brands, places, things, and people. Other brands include co-branding with other brands including the reputation of other companies, corporate alliances. Places includes communication channels used by companies to communicate. People related to employees, or endorsers. Things are related to organizing certain events, communities, government or forums. Strengthening these elements will be pursued through a number of partnerships incorporated in stakeholder approaches, such as government, employees, social institutions, communities, and other companies. This stakeholder approach is an aspect of partnership that can later support WAI's performance to strengthen brand knowledge and the longterm sustainability of the company.

\section{Research Questions}

1) How to apply the secondary association leverage for brand strengthening?

2) How is the implementation of stakeholder approaches to support brand strengthening and the sustainability of the company? 


\section{IJBE}

International Journal of Business Economics, 1(1), 59-75, September 2019 http://jurnal.umsu.ac.id/index.php/ijbe

eISSN 2686-472X

In this study there are three main objectives, first, knowing the application of secondary association leverage in strengthening the Wanderlust company brand products. Strengthening the brand through secondary association leverage not only sees how the achievements of external competitors but also reinforces the company's internal components. Second, knowing the implementation of stakeholder approaches in supporting brand strengthening and the sustainability of WAI. The implementation of stakeholder approaches leads to providing a picture of the partnership that has been built so far in its efforts to strengthen product awareness to consumers. Third, to determine the extent to which the application of secondary association leverage, whose main orientation is in strengthening the brand and the sustainability of the company, basically directly or indirectly reinforces the cultural products of one region. Tourist destinations as one of the main components of the company's sales products are inseparable from the cultural products in them. In its efforts to strengthen the product brand, the strengthening of cultural products will automatically become an important component. This cultural product which in the study of Matsumoto and Juang (2003) refers to subjective aspects (behavior, beliefs, attitudes, values etc.) and objective aspects (food, clothing, equipment and so on).

\section{Stakeholder Approach}

Freeman (2013), defines stakeholders as a group that has an influence and there is an impact on achieving a company goal. Henriques and Sadorky (1999) also explain that there are 4 categories of groups in stakeholders, namely:

1) Organizational Stakeholders, consisting of employees, consumers, shareholders, and suppliers;

2) Community Stakeholders, consisting of local communities and groups that have interests;

3) Regulatory Stakeholders, consisting of those who make regulations in each region and

4) Media Stakeholders, consisting of media parties who publish news.

Donaldson and Preston (1995) also describe stakeholders in 8 groups, namely:

1) Government: government institutions that compile regulations in the course of the economy. The mechanism and corporate governance are determined by regulations made by the government.

2) Investors: are parties that invest in the company, and company management has a strong responsibility to maximize the investment that has been given.

3) Political Groups: groups that have political influence, including non-governmental organizations (NGOs), social communities, and cultural communities.

4) Customer: consumers from related companies. Consumers have a concern for consumption of production, and the transparency of product composition wants to be known by consumers.

5) Communities: local people who are directly or indirectly affected by the company's business activities.

6) Employees: parties are directly related internally from the running of the company. Employees must be economically prosperous in order to be able to optimally contribute to the company.

7) Trade Association: trade associations have an influence on the formation of trade rules of each member, so companies associated in the association must comply with regulations that have been agreed to be implemented. 


\section{IJBE}

International Journal of Business Economics, 1(1), 59-75, September 2019 http://jurnal.umsu.ac.id/index.php/ijbe

eISSN 2686-472X

8) Suppliers: those who supply raw materials to companies to carry out production activities, the influence of suppliers is very large because the company has a predetermined production time so that operational activities run smoothly according to plan.

\section{Brand Equity}

Brand equity is often associated with brand strength (Morgan, 2000). However, brand equity is also always associated with 'net worth' problems in financial terms. Brand equity also means 1) an asset that must be managed; 2) generate cash flow; 3) increase in market share; 4) premium prices; 5) reduction in promotion costs; 6) increase the leverage of the brand; 7) tend to be stable in times of fluctuation; 8) not vulnerable to competition. Brand equity also means a strong brand. This strong brand has a big name and consumers can interpret the existence of a strength, the availability of brands in the market, strong distribution and good promotion. In addition, a strong brand is also related to quality that is premium and has differentiation. Consumers can distinguish brand attributes from other competing brand attributes. Consumers easily identify strong brands because strong brands can understand consumer desires. A strong brand also shows an affinity aspect, namely the existence of emotional aspects in using the brand and tends to create continuous loyalty in the long run. The main components in brand equity are aspects of function and performance as well as emotional and intangible issues. Function and performance aspects show the main aspects of the reason someone chooses a brand. The emotional aspects and intangible issues are related to the affinity aspect.

Strong brands have a greater number of advantages than weak brands (Hoefffler and Keller, 2003). Strong brands will easily expand their brands by moving to a new product category because consumers will have the same perception that brand extension products have comparable quality. Strong brands have the power to expand the brand line. In addition, consumers have a greater familiarity aspect. The stock market response also increased. Consumers tend not to have price sensitivity on good brands. The strong brand market share tends to outweigh the weak brand market share. Consumer perceptions of information through advertising tend to be positive towards brands that are strong because they have aspects of credibility.

1) The brand equity model proposed by Aaker (1996) shows that brand equity is a number of brand assets and liabilities associated with brands, names, and symbols that increase or decrease the value offered by products or services to companies and corporate consumers. Brand equity can create corporate value through the effectiveness of marketing programs, brand loyalty, premium prices, a conducive environment for brand expansion, and so on. There are five categories of brand equity, namely brand awareness, brand association, perceived quality, brand loyalty, and other assets. Each dimension in brand equity is explained as follows.

2) Brand awareness. Brand awareness consists of brand recognition and brand recall. Brand recognition is brand knowledge about certain aspects of the brand while brand recall is the brand's ability to be remembered by consumers well. Some indicators for measuring brand awareness are 1) I know what brand $\mathrm{X}$ is like; 2) I can know the $\mathrm{X}$ brand among existing brands; 3) I am aware of brand $X$.

3) Brand image. Brand image can be explained through brand associations, favorite aspects, strengths, and uniqueness of brand associations. Brand associations consist of attributes, benefits, and overall brand evaluation. Brand attributes consist of aspects related to nonproducts such as price, packaging, and users; while those relating to attributes are color, size, 


\section{IJBE}

International Journal of Business Economics, 1(1), 59-75, September 2019 http://jurnal.umsu.ac.id/index.php/ijbe

eISSN 2686-472X

and design features. Regarding benefits, this can consist of functional, symbolic, and experiential aspects. Some indicators for measuring brand image or brand association are 1) the characteristics of the X brand I can remember quickly; 2) I can remember the X brand symbol or logo; 3) I easily imagine the $\mathrm{X}$ brand.

4) Quality perception. This relates to the individual's interpretation of the quality of the product. Some indicators for measuring perceived quality are 1) brand $X$ is considered high quality; 2) the quality of brand $\mathrm{X}$ is considered higher than other brands; 3 ) the quality of brand $\mathrm{X}$ will always be consistent.

5) Brand loyalty. Some indicators for measuring brand awareness are 1) not going to move to another brand; 2) brand $\mathrm{X}$ is always the first choice; 3 ) recommend to others to use brand $\mathrm{X}$.

6) Other proprietary assets. This asset includes patents, trademarks.

\section{Leverage Secondary Association}

Leverage secondary association (LSA) is a concept that explains related to techniques for developing brand equity. The development of brand equity is an initial step so that brands can be known, understood and liked and eventually used as an option to meet consumer needs. LSA according to (Keller, 2013) consists of elements which are collaboration of various aspects to strengthen brand names. Figure 1. shows the strengthening of brands supported by four main elements, namely people, places, things, and other brands. These four elements are optimized to support the brand so that brand equity can be created. Each of these elements is said to be a stakeholder of a brand that collaborates with each other to enhance brand reputation. Brands cannot excel alone, but require a number of aspects that support the brand's long-term existence.

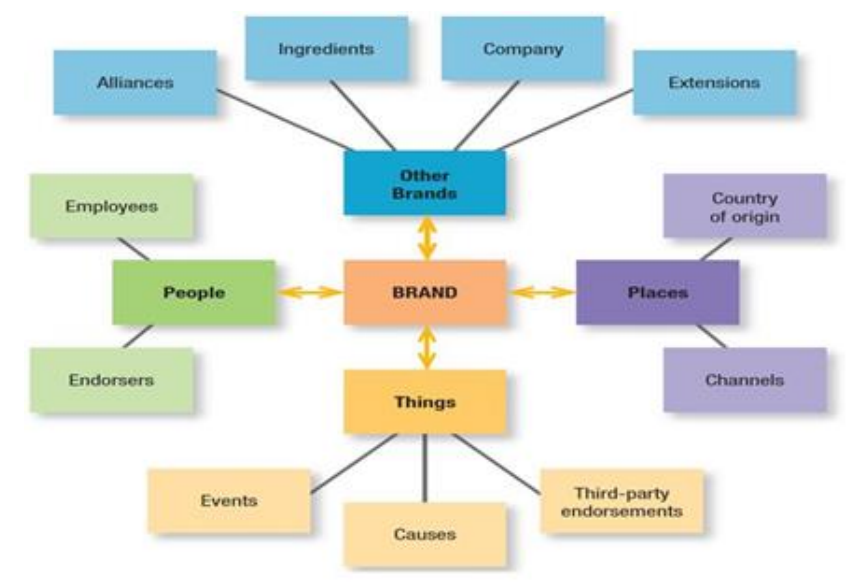

\section{People}

Figure 1. Leverage Secondary Association, (Keller 2013)

This aspect of people is related to individuals who have a role to support brand performance. There are two aspects to people, namely employee and endorsers. An employee or employee is an important component that has the benefit of being able to contribute to the benefits of the brand. Employees, who participate in serving well to consumers, will create a good corporate reputation for the brand. Employees can act as consumers who use products so that this can strengthen the company's external consumers related to product quality. When employees are brave or willing to 


\section{IJBE}

International Journal of Business Economics, 1(1), 59-75, September 2019 http://jurnal.umsu.ac.id/index.php/ijbe eISSN 2686-472X

use products, this will affect consumers' confidence to be willing to use the product. The company needs to do internal branding or internal marketing to its employees so that what is conveyed by the company to external consumers is in line with what is conveyed by the company to internal consumers. In essence, internal branding aims to harmonize external consumer perceptions of the company's image with employee perceptions of the company's image. It is intended that the company consistently deliver messages about brand attributes to consumers with what is perceived by employees. This is done so that the company does not seem to be just merely looking for selfimage. Employees also need to be given socialization so that they are also consistent in behaving and behaving in the same way as what is communicated by the company to consumers.

In people, there are also endorsers. Endorser is a medium in marketing communication that is useful for the purpose of communicating a brand. Endorser is a person who is a star or actress or actor who supports the product being promoted. Endorsers are also defined as certain figures who convey a message or demonstrate a product or service in a promotional activity directly (direct source) in order to support the effectiveness of delivering messages to a product (Belch \& Belch, 2015). Endorsers as individuals who are considered as celebrities or who have expertise in a field of products or services that speak on behalf of the company. Endorsers are not only limited to individuals who have used a product or service because the endorser's job is to convey a message or demonstrate a product or service to the target market.

\section{Things}

Things are considered capable of improving development and supporting brand performance. There are three aspects in things namely event, third party endorsement, and causes. Events can increase brand awareness because consumers get exposure to information. Events held can be activities that can indirectly promote products so that consumers can find out about the benefits of the brand. This event can also be aimed at getting closer to consumers emotionally (Chakraborti \& Roy, 2013).

Third party endorsement is a party outside the company that indirectly supports brand performance and brand strengthening. Superior brand choices can support brand reputation in the long run. A brand that is supported by a number of brands with excellent quality will support better brand performance. These supporting brands can provide benefits, namely (Kotler and Pfoertsch, 2006) as follows, namely:

1) As a differentiator (Differentiation) -branding is an effective and interesting way to "decomoditize" highly differentiated product categories.

2) Supporting future business.

3) It is very important to build a brand in order to prepare a business in the future. In the business world, companies that are able to survive in competition are companies that have built their brands from the start. With a strong brand, it will be easier to withstand all kinds of crises and be able to attract markets and investors.

4) Creating loyalty

5) Brand helps companies in the process of changing from transaction-based selling models to relationship-based models. Customers will always come first. Loyalty is formed when businesses succeed in consistently delivering brand promises.

6) Being the main choice. A strong brand will prevent customers from switching to competing products or services. This makes the brand a top choice against competition. 


\section{IJBE}

International Journal of Business Economics, 1(1), 59-75, September 2019 http://jurnal.umsu.ac.id/index.php/ijbe

eISSN 2686-472X

7) Creating premium prices. A business with a well-known brand can create premium prices for their products and services. Customers will want to pay more for a trusted brand. This will make the company stronger in facing competition.

8) Creating a brand image. Brands activate the company's value proposition to be more emotional and attractive. A positive brand image will also appeal to all other stakeholders, making it easier to recruit and retain human resources

9) Increase sales. Naturally the big goal of companies doing business is to make a profit. With a strong brand, companies can benefit not only from higher margins but also from higher sales volumes.

Regarding causes, cause is an activity or program implemented to support brand performance. This cause can be social activities that contribute to society. This cause activity is related to social programs such as social marketing, cause marketing, corporate social responsibility or other social activities. This activity is expected to improve the reputation of the company perceived not only to be oriented to profitability.

\section{Places}

In places there are two elements, namely country of origin and channel. Country of origin or country of origin shows individual beliefs about the origin of a product or service. This can be taken into consideration by individuals to evaluate a product to be purchased (Acharya \& Elliot, 1998). For some individuals the country of origin of a product is very important. On the one hand, some consider products from their own country to be better than products from other countries. However, on the other hand, there are also those who act to accept products from other countries from other countries. Country of origin perceptions are mental associations and beliefs that are influenced by the state. The government formally wants to improve the country's image by helping local marketers who export and also to attract foreign companies to investors. According to Bloemer et al., (2009), home countries can influence the evaluation of a product and buying behavior through cognitive processes. A product will consist of various information such as physical form, design, raw material, color, taste, and performance, which directly represent the internal point of view and reputation, brand equity, price, brand name, and country of origin representing external aspects according to Liefeld (1993).

Another place element is channel. The importance of value creation is also driven by value delivery. Development of distribution networks also determines the perception of the value received by consumers. Distribution guarantees the arrival of goods or services sent from manufacturing companies to the final hands of consumers. Companies tend not to sell their products directly to consumers, but use intermediaries to be able to channel their products through marketing channels or marketing distribution. Marketing channels are a number of independent organizations that participate in the process of making goods and services available to be consumed or used. In addition to channel related, the development of e-channels is actually driven by consumer power. Consumers have the ability to buy and increase knowledge so that they can determine the companies that serve well through online retail. Companies are also increasingly aware that information about consumers is very important and must be obtained quickly. The speed of information obtained by companies can help companies develop marketing strategies. The company is in a very competitive industry and is accompanied by many players. Geographical 


\section{IJBE}

International Journal of Business Economics, 1(1), 59-75, September 2019 http://jurnal.umsu.ac.id/index.php/ijbe

eISSN 2686-472X

problems are no longer a problem in trying to get closer to consumers. Consumers can interact directly with companies without any distance and time constraints (Mayasari, 2012).

\section{Other Brands}

Components of brands in supporting brand development include alliances, ingredients, company, and extensions.

1) Alliances are related to cooperation with other parties that can be co-branding. This collaboration is intended to complement the shortcomings between brands. By having complementary characteristics, each brand will support the existence of other brands. Cobranding, for example, will strengthen the performance of major brands, because there is a brand strength that is attached to the main brand. Other alliances, for example, are the carrying capacity of each brand's performance, so that this can improve brand performance.

2) Ingredients. A working brand consists of the main components that support the overall performance of the brand. Choice of brands from suppliers or partners will support the company's reputation. Each of these brands has advantages.

3) Company. Other companies also have a role to support brand performance. This company can be a partner who indirectly supports for example a competing company, government, foundation, or other organization. Collaboration with other organizations can support companies to be able to take benefits that can support brand performance.

\section{RESEARCH METHOD}

This study uses a qualitative approach as a method for data retrieval. Case study research raised in this regard relates to the existence of tour and travel companies under the name of WAI in strengthening the company's brand awareness to date. The existence of WAI as one of the tour and travel companies that opens anti-mainstream travel and travel routes oriented to areas that are not well known by tourists is one of the uniqueness that needs to be studied more deeply with the case study approach. Efforts to understand the process of strengthening corporate brand awareness through the concept of secondary association leverage, the intrinsic case study approach is the right method with the basis of the uniqueness of a case. A decision, a social program, a process or situation changes (Perry, 2004). In this study, the analysis unit that will be the focus of research is the process that has been carried out by WAI tour and travel companies in strengthening the company's brand with the Leverage Secondary Association approach. In this study, the types of data collection that will be conducted are interviews and secondary reports which are considered able to provide holistic information in an effort to provide a complete picture related to the process of strengthening WAI tour and travel company brands with the Leverage Secondary Association approach.

Interview is one method of data collection that is generally widely used in qualitative approaches. In the case study setting, the use of interviews is one method that is generally used to obtain information in accordance with the research question that you want to address. The interview itself is a conversation that has a specific purpose which in the process involves interviewers who ask questions and interviewees who answer questions (Moleong, 2004). The interview approach in qualitative research is generally inseparable from the interview function which is considered to be better able to provide the right description and exploration than using other approaches (Banister in Poerwandari, 2005). In this case, the interview approach is the most appropriate method in its 


\section{IJBE}

International Journal of Business Economics, 1(1), 59-75, September 2019 http://jurnal.umsu.ac.id/index.php/ijbe

eISSN 2686-472X

efforts to explore the processes carried out by WAI in strengthening branding using the Leverage Secondary Association approach.

Data analysis in qualitative research according to Creswell (1998) basically represents 6 stages, namely data management managing, reading-memoing, describing, classifying, interpreting and representating-visualizing. The emphasis in data analysis in the case study is the existence of detailed descriptions of cases as well as surrounding settings / situations.

\section{RESULTS AND DISCUSSION \\ Results \\ People}

\section{1) Company Partner.}

The company partner that is considered important is the Ministry of Manpower. Introducing the department was facilitated because there were colleagues from the owner who happened to work in the department. This collaboration began with acquaintances who could be considered as media making it easier to get a bigger market. In addition to partners from the government, WAI also collaborates with corporations. The initial corporation that was established was Bank Mandiri. This is made easy because there is a brother from the owner who also works at the company. Bank Mandiri at that time asked to be assisted in managing the desire to carry out private property for priority customers. From there it will be word of mouth for others.

Respondent 1: yes they are more on official trips and if there is a working meeting they ask to be taken care of all with Wanderlust. Then coincidentally because Veni's sister worked independently ... yes ... first from her place of work her sister asked for her office vacation asking for an end, it went on ... now we like being asked to be independent private for independent customers whose funds are above that much ... (Hanie, 13 November 2018)

\section{2). Target market of Wanderlust.}

The target market of WAI is not specific to certain groups. This was formed because of a number of requests that could come from all walks of life. The target market can be from students, families, and companies. Consideration for targeting all groups because they still have sufficient resources and will also look for markets that will later be established.

Respondent 1: Actually, Wanderlust is formed because of market demand. We have never specified oh we are specifically in the eastern part and we have just played in gathering offices. but if we are students we also serve. So it's better for the guests to be satisfied with their repeat order strategy for us or to be recommended to their people if they want to buy a ticket ... (Hanie, 13 November 2018)

\section{3). The challenges in Partnership.}

WAI has provided an interesting offer, but the name WAI still does not create awareness for the community. Of course this is a good indicator for WAI. The marketing program including word of mouth is not optimal because many people do not know WAI. One indicator that shows this is that there are only a few followers on social media, whether Facebook, Instagram or Youtube. WAI believes that it can provide better services than other tour and travel companies. The new strategy is related to strengthening the image so that it is embedded in the minds of 


\section{IJBE}

International Journal of Business Economics, 1(1), 59-75, September 2019 http://jurnal.umsu.ac.id/index.php/ijbe

eISSN 2686-472X

consumers regarding the brand. New strategies are sought to be able to increase brand awareness and can improve good image so that it can be widely known by the general public as potential customers and more can be embedded in the minds of WAI customers and tourists.

Respondent 1: if it's a challenge ... if our dream is more people, if they want to go for a walk, remember the wanderlust. His wish is like that huh. Like people who want to buy tickets, isn't it, people of Taunya Traveloka, because they are application-based and really big. (Hanie, 13 November 2018)

\section{4). Partnership in Branding.}

The development of the partnership by WAI decided that consumers were also partners. This consumer is an important partner of WAI because WAI's customer satisfaction can be an important promotional tool for WAI to get new consumers or old consumers to reuse it. This can be viral because one satisfied consumer will upload experience with WAI on their social media so that this can be an aspect of WAI's promotion for free and more convincing to other consumer candidates.

Respondent 2: e ... the first one was before a few followers have now increased. So it's still playing in followers and playing gives away. Give away is also good ... so suppose we ask them to post your holiday photos with the captions as attractive as possible and invite 3 friends to tag the 3 of your friends. So, for example, I want to share with 3 other friends so what I didn't know beforehand is what it is. So the partners themselves also include their own customers (Venny, 13 November 2018)

\section{5). The business strategy of collaboration with the partner.}

Another business partner is collaborating with companies related to wista. WAI also developed a new market by targeting PLN Jayapura. The East region is a target for WAI managers because the potential of the area to visit has a good view. Community interest has increased. Other WAI partners are related to tourism managers, namely hotels, local tourism managers, restaurants, and local photographers.

Respondent 2: PLN has just recently. Just new last month. So what do you want ... gathering but actually already have an EO but there is a problem with the EO finally looking for the theme ... hehehe met us but already h-week the management paid for the first EO but we arranged the ticketing (Venny, November 13, 2018)

\section{6). Partnership.}

The partnership process is an aspect starting from scanning in the beginning, namely understanding the partners first. The selected partners are of course partners who can meet WAI's needs and are in line with WAI's vision. WAI also sometimes conducts surveys to get to know the prospective partners.

Respondent 2: yes ... so we surveyed also ma'am ... we survey first and then we chat. So there we might not just ... for example if we go to Merapi, we chat, who is it that is better, and it seems like it's sticking with him and his service is ok, so keep on going. ... (Venny, 13 November 2018). 


\section{IJBE}

International Journal of Business Economics, 1(1), 59-75, September 2019

http://jurnal.umsu.ac.id/index.php/ijbe

eISSN 2686-472X

\section{7). The impact of partnership.}

The partnership effect takes the form of implications for WAI's performance. The performance of the collaboration based on the agreement for profit sharing from the acquisition of services from partners includes restaurants, travel agents, and souvenir shops. This collaboration is considered beneficial because profit sharing is based on agreement between partners.

Respondent 1: They believe that they are partnering with local governments because we give them guests right. They also have to achieve right. Fulfill their quota, for example, we bring 40 guests. Continue to place souvenirs ... (Venny, November 13, 2018)

WAI also never experienced conflicts with partners, because everything went well. It seems that each WAI partner has mutually beneficial benefits so that he can continue to collaborate.

Respondent 1: There is nothing and do not arrive. (Hanie, 13 November 2018)

Respondent 1: can still be tolerated. yes, for example, rich transportation is 5 minutes late. If the reason is acceptable, then it's okay. Then if the hotel doesn't have any ... (Hanie, 13 November 2018)

\section{Places}

\section{1). The way the company to communicate.}

Location determination is a way for WAI to develop its business properly. This location is important for WAI because it is a value proposition offered by companies to consumers related to tourism benefits and other offers. This offer is related to the destination and the accompanying packages. To choose a location, WAI partners with local people who have good knowledge of a region. As such, they will notify WAI of the potential of the region that is considered good.

Respondent 1: definitely ... definitely determines new destinations. Certainly if not many people open the new destination and people who want to go to that destination are few choices. So the possibility of a wanderlust to be chosen is also greater than for example how many hundred trips there are already so many travels. What choices are more ... consumers have more choices. Bbandaneira ... ambon. we want to open in March. (Hanie, 13 November 2018)

\section{2). The efforf of company to go international.}

WAI seeks to develop markets not only in the orientation of the domestic market, but also in international markets such as Thailand and Singapore. This market development is actually to be able to expand the intended location. But its nature is still waiting on order and is package. The consequence is to develop cooperation with local partners which allows to facilitate customer service there.

Respondent 1: Yes, Thailand is rich, Singapur ... Yes that is without a visa. (Hanie, 13 November 2018)

\section{3). The company strategy to promote.}

WAI organizes a number of events in order to be able to introduce its programs to consumers. The program can be done by inviting other consumers to open trips, especially people who have expertise in the field of traveling. This open trip is usually held twice a year. 


\section{IJBE}

International Journal of Business Economics, 1(1), 59-75, September 2019 http://jurnal.umsu.ac.id/index.php/ijbe

eISSN 2686-472X

Respondent 1: okay ... for next year it's still open trip. 2 times a year. The bias in the open trip is that we invite influencers. Famous people in the field of traveling.

(Hanie, 13 November 2018)

\section{Things}

\section{1). The challenges and problems.}

WAI realizes that there must be many competitors in the same field. Therefore, WAI actually realizes the importance of uniqueness to differentiate from competitors. However, WAI is still considering the characteristics of companies that are still beginners, so WAI is looking for the right form. WAI realizes that indeed today, it still benefits from ongoing demand. During this time, what distinguishes WAI from other parties is that the owners go down directly in managing so that they have a sense of serving consumers well.

Respondent 1: e ... still looking for patterns because we are rich again, we said we were lucky, there is always a request. (Hanie, 13 November 2018)

\section{2). Event of the company.}

WAI realizes that in order to improve the quality of existing services, including maintaining good relations with consumers who have used WAI, companies need to develop programs to continue to be able to communicate with their conferences.

Respondent 2: with guests, yes ... if we are just because the trip has a whatapps group so after the trip it doesn't stop just there. Sometimes we, if we are free, like to hang out with them even though only one of them is rich. (Venny, November 13, 2018)

\section{Other Brands}

\section{1). Positioning of Wanderlust.}

In the business development process, it seems that WAI does not show a definite positioning. However, based on interviews, WAI has a value proposition related to tourism services that can be unique to WAI. The value proposition includes 1) warmth and kinship that can strengthen comfort for tourists, 2) giving stunning tourism sites that are the focus of WAI to continue to look for new tourist sites that are unique and not visited by many, 3) giving priority to travel safety through providing travel insurance, and 4) providing documentation facilities in the form of photos and video support.

\section{Discussion}

Regarding people, based on interviews, WAI considers that people here can be from companies and brand endorsers, even consumers. WAI owners themselves turned out to be an important party that has the benefit of being able to contribute to the benefits of the brand and participate in serving well to consumers, thus creating WAI's good reputation for the brand. WAI also uses people, there are also endorsers. Endorser is a medium in marketing communication that is useful for a purpose of WAI communication. Endorser WAI is an adventurous person and an 


\section{IJBE}

International Journal of Business Economics, 1(1), 59-75, September 2019 http://jurnal.umsu.ac.id/index.php/ijbe eISSN 2686-472X

expert in his field so that he can deliver a message or experience from a visit of several tourist areas.

Regarding things, things are considered capable of increasing development and supporting the performance of the WA brand. In this case, WAI uses an open trip event to increase brand awareness because consumers get exposure to information. The events held can be activities that can indirectly promote WAI so that consumers can find out about the WAI brand.

Regarding places, WAI is following the development of digital business so that this can facilitate consumers to access WAI. WAI realizes that information about tourism for consumers is very important and must be obtained quickly. The speed of information obtained by WAI can help companies develop marketing strategies. Geographical problems are no longer a problem in trying to get closer to consumers. Consumers can interact directly with companies without any distance and time constraints. In addition, WAI also collaborates with local partners to be able to promote WAI to consumers.

Strengthening the brand with the concept of secondary association leverage is through a stakeholder approach. The stakeholder approach includes a variety of interests, not just the interests of consumers. This perspective considers a number of interests, namely the government, nongovernmental organizations, competitors, consumers and employees. Strengthening the brand from the consumer side, of course the company will provide high quality products and benefits. WAI can be maintained if it has attention to all stakeholders as partners. In the government, companies that manage brands show concern in collaborating with regard to cooperation as well as ultimately being able to contribute to the payment of certain levies. With competitors, WAI seems to be able to work together to collaborate because this collaboration is considered as a way to increase each other's profits. Other partner aspects can also provide the strength of the WAI brand by establishing good cooperative relationships so that WAI can be easily recognized by consumers including cooperation with hotels, travel agents and even consumers themselves.

\section{CONCLUSION}

Based on the results of empirical research that has been done it can be concluded that the leverage secondary association in the Wanderlust company has shown strength in the company. This can be seen from the four elements that support it, namely people, places, things, and other brands. These four elements have been optimally carried out by Wanderlust to support the sustainability of his company in order to create equity in his company.

1) People: Wanderlust collaborated and partnered with various institutions such as Depnaker, Mandiri, PLN and several corporate and private sectors. In running the company, there are various challenges including marketing strategies. According to the source, it was important for them to be able to develop a business strategy to be able to develop their company. In addition to posting advertisements on social media such as Instagram, they are currently maintaining a level of customer satisfaction. This is important so that future customers continue to use WAI services and can provide recommendations to people or relatives of customers. In addition, partnering with similar companies is their business strategy to continue running their collaborative programs.

2) Places: WAI in carrying out its business of communicating with various parties such as the hotel, partners (existing teams) or local partners where the destination is. The role of local 


\section{IJBE}

International Journal of Business Economics, 1(1), 59-75, September 2019 http://jurnal.umsu.ac.id/index.php/ijbe

eISSN 2686-472X

partners becomes important in providing better recommendations for new places to deepen further.

3) Things: WAI as a newly established company certainly has various challenges and problems including maintaining customer satisfaction and trust. In addition, there are several activities to improve their quality by giving them the attraction of giving away, namely giving gifts in the form of a trip to partners and users through posting holiday photos with captions that are as attractive as possible and inviting 3 friends to tag to your 3 friends. This aims to introduce Wanderlust.

4) Other brands: WAI is still looking for patterns to always develop branding, currently still limited to requests from existing customers or partners. Every year, there is an increase that must be achieved and always give the best. The difference between WAI and the same service is during the trip to the destination owner or the owner who runs it directly. To maintain and strengthen awareness of the company, the most important thing is to provide satisfaction and maintain relations with its partners, establish collaboration to enhance WAI's reputation.

WAI as a company that has only officially operated for 2 years is expected to be able to maintain the sustainability of the company in the future. There are several suggestions that can be given, including:

1) Using social media more massively with a target not only for young people, but also for all groups.

2) Utilizing endorsers from artists or personal bloggers, who also have a hobby of traveling who use WAI services, can be started from relationships that are considered quite famous.

3) Maintain a reputation by maintaining customer trust.

4) Providing other attractions, such as the appearance or promotions of tourist destinations that can invite customers to choose Wanderlust for all groups.

5) Utilizing consumer testimonials who already have experience using WAI services so that they can attract the attention and interests of other consumers. Provide rewards in the form of price discounts or additional services to consumers who upload testimonials on social media. This can promote a product through influencers on social media such as Instagram, Youtube, Twitter, blogs, and others. Influencers are people who have many followers on social media and have a strong influence on their followers so that what they convey and do can influence followers to try and buy a product, in this case especially traveling lovers.

6) WAI is expected to be able to participate in activities related to the tourism business held by a community, local government or association so that the community or target market has the opportunity to see and get to know WAI for example a travel fair.

7) Collaborating with local governments as partners and traveler communities so that they can be the first choice when there are requests for tourism trips to the area.

8) Fix the website that can provide detailed information related to various types of facilities, such as: tour package list, tour package prices, search ticket features, interesting travel photos and videos so that they can be added value to WAI.

\section{REFERENCES}

Aaker, D.A. (1996). Measuring Brand Equity Across Products and Markets. California Management Review, 38, 10-20. 


\section{IJBE}

International Journal of Business Economics, 1(1), 59-75, September 2019 http://jurnal.umsu.ac.id/index.php/ijbe

eISSN 2686-472X

Acharya, C., \& Elliot, G. (2003). Consumer Ethnocentrism Perceived Product Quality. Journal of International Consumer, 87-115.

Andrews, R. and Entwistle, T. (2010). Does cross-sectoral partnership deliver? An empirical exploration of public service effectiveness, efficiency, and equity", Journal of Public Administration Research and Theory, 20, 679-701.

Belch, G.E. \& Belch, M.A. (2015). Advertising and Promotion: An Integrated Marketing Communicative Perspective. Global Edition. Singapore: Mc-Graw-Hill.

Bloemer, J., Brijs, K., \& Kasper, H. (2009). The CoO-ELM model: A theoretical framework for the cognitive processes underlying country of origin-effects. European Journal of Marketing, 62-89.

Chakraborti, R. \& Roy, S. (2013). Meaning transfer between events and sponsor brands: Integrating the role of emotions-a new conceptual framework. Journal of Brand Strategy, 2 (1), 87-105.

Creswell, J., W. (1998). Qualitative Inquiry And Research Design: Choosing Among Five Traditions. California: SAGE Publications.

Donaldson, T., \& Preston, L. (1995). The stakeholders theory of the corporation: Concepts, evidence, and implication. Academy of Marketing Review, 20 (1), 65-91.

Gibson, K. (2012). Stakeholders and sustainability: An evolving theory. Journal of Business Ethics, $109,15-25$.

Freeman, E. (2006). Company stakeholders company: The new approach of CSR. Business Roundtable Institute for Corporate Ethics, 2-13.

Gouillart, E. (2008). An interview with C.K Prahalad. Journal of International Affairs, 65, 215.

Hoeffler, S. \& Keller, K.L. (2003). The Marketing Advantages of Strong Brand. Journal of Brand Management, 10, 421-445.

Richard, J. (2005). "Finding Sources of Brand Value: Developing a Stakeholder Model of Brand Equity," Journal of Brand Management, 13, 10-32.

Keller, K. L. (2013). Strategic Brand Management: Building, Measuring, and Managing Brand Equity. Boston: Pearson.

Kotler, P. \& Pfoertsch, W. (2006). B2B Brand Management. Berlin: Springer.

Liefeld, J. P. (2004). Consumer Knowledge and Use of Country-of-origin Information at the point of purchase. Journal of Consumer Behaviour, 85-87.

Matsumoto, D., \& Juang. L. 2003. Culture And Psychology (3rd ed). New York: Wadsworth.

Mayasari, I. 2012. Manajemen Pemasaran. Jakarta: Green Tea.

Mayasari, I. 2018. Framework of Partnership. Modul Program untuk Executive Program for Sustainability Partnership.

Moleong, L. J. (2004). Metodologi penelitian kualitatif. Edisi Revisi. Bandung: PT Remaja Rosdakarya.

Perry, D. E. (2004). Case Studies. Accessed http://www.google.co.id/url?sa=t\&source=web\&rct=j\&url=http://users.ece.utexas.edu/

Poerwandari, E. K. 2005. Pendekatan kualitatif untuk penelitian perilaku manusia. Jakarta: Lembaga Pengembangan Sarana Pengukuran dan Pendidikan Psikologi Fakultas Psikologi Universitas Indonesia.

Richards, L. (2005). Handling qualitative data (A practical guide). London: SAGE Publications. Morgan, R.P. (2000). A Consumer-Orientated Framework of Brand Equity and Loyalty," International Journal of Market Research 42, 65-78. 


\section{IJBE}

International Journal of Business Economics, 1(1), 59-75, September 2019

http://jurnal.umsu.ac.id/index.php/ijbe

eISSN 2686-472X

Russo, A. \& Perrini, F. (2010). Investigating stakeholder theory and social capital: CSR in large firms And SMEs. Journal of Business Ethics, 91, 207-221.

Prodjo,W.

https://travel.kompas.com/read/2016/10/27/084100327/kembangkan.pariwisata.ini.hambata n.dan.tantangan.kemenpar

Verbeke, A. and Tung, V. 2013. The future of stakeholder management theory: A temporal perspective. Journal of Business Ethics, 112: 529-543.

Wallstrom,A., Karlson,T., Sangari, E.S. 2008. Building a Corporate Brand: The Internal Brand Building Process in Swedish Service Firms. Journal of Brand Management 16: 40-50. 